JURNAL ILMU KESEHATAN BHAKTI HUSADA:

HEALTH SCIENCES JOURNAL

VOL. 12 NO. 02, DESEMBER 2021

DOI: $10.34305 / \mathrm{JIKBH} . \mathrm{V} 12 \mathrm{I} 2.327$
Ciptaan disebarluaskan di bawah

Lisensi Creative Commons Atribusi-

NonKomersial-BerbagiSerupa 4.0

\title{
KESEHATAN MENTAL PADA PENYINTAS COVID-19: A LITERATURE REVIEW
}

\author{
Nur Wulan, Budi Anna Keliat \\ Universitas Indonesia \\ nurwulan1994@gmail.com
}

\begin{abstract}
Abstrak
Pandemi COVID-19 memberikan dampak bukan hanya pada yang terkonfirmasi, namun juga pada mereka yang dinyatakan sembuh. Penyintas COVID-19 rentan untuk mengalami masalah kesehatan mental. Pemahaman tentang masalah dan tantangan yang dihadapi para penyintas COVID-19 perlu dilakukan untuk menetapkan kebijakan yang dapat meningkatkan kesehatan dan kesejahteraan mereka secara efektif. Artikel ini bertujuan untuk mengidentifikasi masalah kesehatan mental yang dihadapi oleh penyintas COVID-19. Kajian ini menggunakan desain studi literatur melalui Proquest, Science Direct, Scopus dan Google Scholar dengan kata kunci COVID-19, survivor and mental health dari tahun 2019-2021. Kecemasan, depresi, PTSD bahkan bunuh diri menjadi masalah kesehatan yang dapat ditemukan pada penyintas COVID-19. Guna mengatasi hal tersebut perlu adanya layanan konsultasi yang efektif untuk mendukung penyintas COVID-19 yang dipulangkan, seperti penjelasan gejala fisik atau implikasi medis dari hasil tes ulang.
\end{abstract}

Kata kunci : COVID-19, Depresi, Kesehatan mental, Kecemasan, Penyintas, PTSD

\section{Pendahuluan}

Sejak Desember 2019, pandemi COVID-19 telah menarik perhatian dunia karena penyebarannya yang cepat dan eksponensial (Forte et al., 2020). Berdasarkan data WHO per tanggal $28 \mathrm{Mei}$ 2021 sebanyak 113 negara yang melaporkan tentang COVID-19. Total ada 169.021.406 di seluruh dunia yang dinyatakan terkonfirmasi COVID-19. Indonesia menjadi salah satu negara yang memiliki grafik kasus harian yang fluktuatif dengan jumlah total 1.803.361 yang terkonfirmasi. Sebanyak 1.654.557 dinyatakan sembuh dan 50.100 dinyatakan meninggal (C. Wu et al., 2020). Hal tersebut menunjukkan bahwa 
JURNAL ILMU KESEHATAN BHAKTI HUSADA:

HEALTH SCIENCES JOURNAL

VOL. 12 NO. 02, DESEMBER 2021

DOI: $\underline{10.34305 / J I K B H . V 12 I 2.327}$

angka sembuh (penyintas) lebih banyak dibanding yang meninggal.

Beberapa studi setuju bahwa pandemi ini berdampak fisik maupun psikologis serta bukan pada orang sehat, yang terkonfirmasi bahkan yang telah dinyatakan sembuh dari COVID19 (Einvik et al., 2021). Karakteristik virus yang dapat menular dengan mudah melalui udara dan droplet membuat pemerintah mengambil kebijakan yang restriktif (Mazza et al., 2020). Banyak yurisdiksi telah menerapkan langkah-langkah pencegahan seperti penguncian, jarak spasial, cuci tangan, dan pemakaian masker wajah (Einvik et al., 2021). Tindakan kuratif dengan metode isolasi mandiri bagi yang gejala ringan sampai sedang dan perawatan di ruang isolasi bagi yang mengalami gejala berat dilakukan untuk menekan penularan, mortalitas dan morbiditas akibat COVID-19 (Cheng et al., 2021; Forte et al., 2020). Namun, hal ini ternyata menimbulkan banyak reaksi psikologis diantaranya stres yang meningkat, ketidakpastian, kesedihan, kecemasan, dan kesedihan (Mazza et al., 2020). Bahkan studi di China menyebutkan penyintas dapat mengalami hal tersebut sebagai dampak psikologis jangka panjang (Mazza et al., 2020).
Ciptaan disebarluaskan di bawah Lisensi Creative Commons AtribusiNonKomersial-BerbagiSerupa 4.0

Internasional.
Studi sebelumnya mengenai wabah pandemi seperti SARS dan Ebola juga menunjukkan adanya dampak kesehatan mental yang dialami oleh penyintas. Penyintas SARS dibebani dengan banyak beban kesehatan termasuk masalah kesehatan fisik dan mental (K. K. Wu et al., 2005). Tantangan yang dihadapi penyintas berupa untuk bekerja, hidup, dan pulih (Susilo et al., 2020). Selama pemeriksaan kesehatan mental pasien dan penyintas teramati bahwa mereka juga mengalami gejala gangguan mental dan disfungsi kekebalan. Selain itu, juga dikemukakan bahwa depresi, kecemasan, dan gangguan stres pasca trauma (PTSD) adalah gangguan mental paling umum yang memerlukan perhatian khusus setelah sembuh (Stuart, 2013)

Pemahaman tentang masalah dan tantangan yang dihadapi oleh penyintas COVID-19 diperlukan untuk mempertimbangkan kebijakan yang dapat meningkatkan kesehatan dan kesejahteraan mereka secara efektif (Susilo et al., 2020). Artikel ini bertujuan untuk mengidentifikasi masalah kesehatan mental yang dihadapi oleh penyintas COVID-19.

\section{Metode}

E-ISSN 2623-1204 P-ISSN 2252-9462 | 216 
JURNAL ILMU KESEHATAN BHAKTI HUSADA:

HEALTH SCIENCES JOURNAL

VOL. 12 NO. 02, DESEMBER 2021

DOI: $\underline{10.34305 / J I K B H . V 12 I 2.327}$
Ciptaan disebarluaskan di bawah Lisensi Creative Commons AtribusiNonKomersial-BerbagiSerupa 4.0 Internasional.
Metode penelitian yang digunakan adalah literature review dengan menggunakan jurnal dari nasional maupun internasional melalui database yang sudah terakreditasi seperti Proquest, Science Direct, Scopus dan Google Scholar dengan kata kunci COVID-19, survivor and mental health. Pencarian literature dilakukan pada tahun 2019- 2020. Data yang digunakan dalam penelitian ini adalah data sekunder yang diperoleh dari hasil studi yang sudah pernah dilakukan sebelumnya. Kelayakan studi dinilai menggunakan PICOT framework (Population, Intervention, Comparison, Outcome, Time) dengan kriteria inklusi sebagai berikut:

\begin{tabular}{lll}
\hline \multicolumn{1}{c}{ PICOS item } & \multicolumn{1}{c}{ Kriteria inklusi } & \multicolumn{1}{c}{ Kriteria eksklusi } \\
\hline $\begin{array}{l}\text { P- } \text { Populat } \\
\text { ion }\end{array}$ & Penyintas COVID-19 & Bukan penyintas COVID-19 \\
I-Intervention & $\begin{array}{l}\text { Artikel yang membahas intervensi yang } \\
\text { dilakukan untuk mengatasi masalah kesehatan } \\
\text { mental yang dialami penyintas COVID-19 }\end{array}$ & $\begin{array}{l}\text { Artikel yang membahas intervensi yang } \\
\text { dilakukan terhadap pasien COVID-19 }\end{array}$ \\
$\begin{array}{l}\text { C-Comparison } \\
\text { O-Outcomes }\end{array}$ & $\begin{array}{l}\text { Masalah kesehatan yang dialami oleh penyintas } \\
\text { COVID-19 }\end{array}$ & $\begin{array}{l}\text { Artikel yang tidak menjelaskan masalah } \\
\text { kesehatan fisik yang dialami oleh penyintas } \\
\text { COVID-19 }\end{array}$ \\
S-Study design & $\begin{array}{l}\text { Deskriptif, cross sectional, kohort, penelitian } \\
\text { kuantitatif/ kualitatif, literature review, } \\
\text { systematic review }\end{array}$ & \\
\hline
\end{tabular}

Berdasarkan kata kunci yang artikel. Berdasarkan 34 artikel yang dimasukkan ke dalam empat database diperoleh kemudian dilakukan pemeriksaan diperoleh total artikel sebanyak 34 artikel. kelayakan berdasarkan kriteria inklusi. Langkah pertama yang dilakukan adalah Sehingga akhirnya jumlah artikel yang mengeliminasi dengan pemilihan full text digunakan dalam studi literatur ini sebanyak dan kesesuaian topik sehingga diperoleh $34 \quad 5$ artikel.

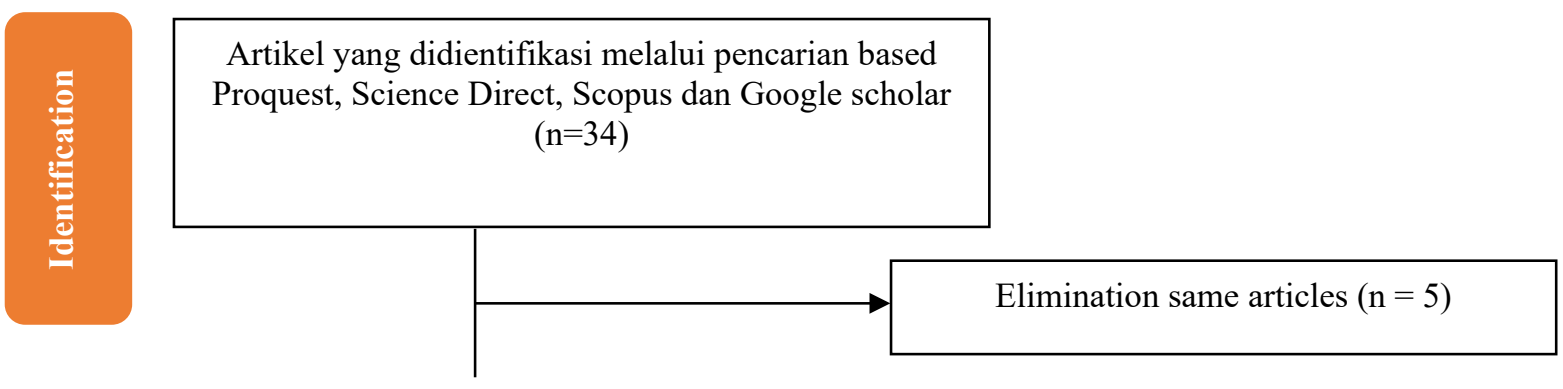


JURNAL ILMU KESEHATAN BHAKTI HUSADA:

HEALTH SCIENCES JOURNAL

VOL. 12 NO. 02, DESEMBER 2021

DOI: $\underline{10.34305 / J I K B H . V 12 I 2.327}$
Ciptaan disebarluaskan di bawah

Lisensi Creative Commons Atribusi-

NonKomersial-BerbagiSerupa 4.0

Internasional.

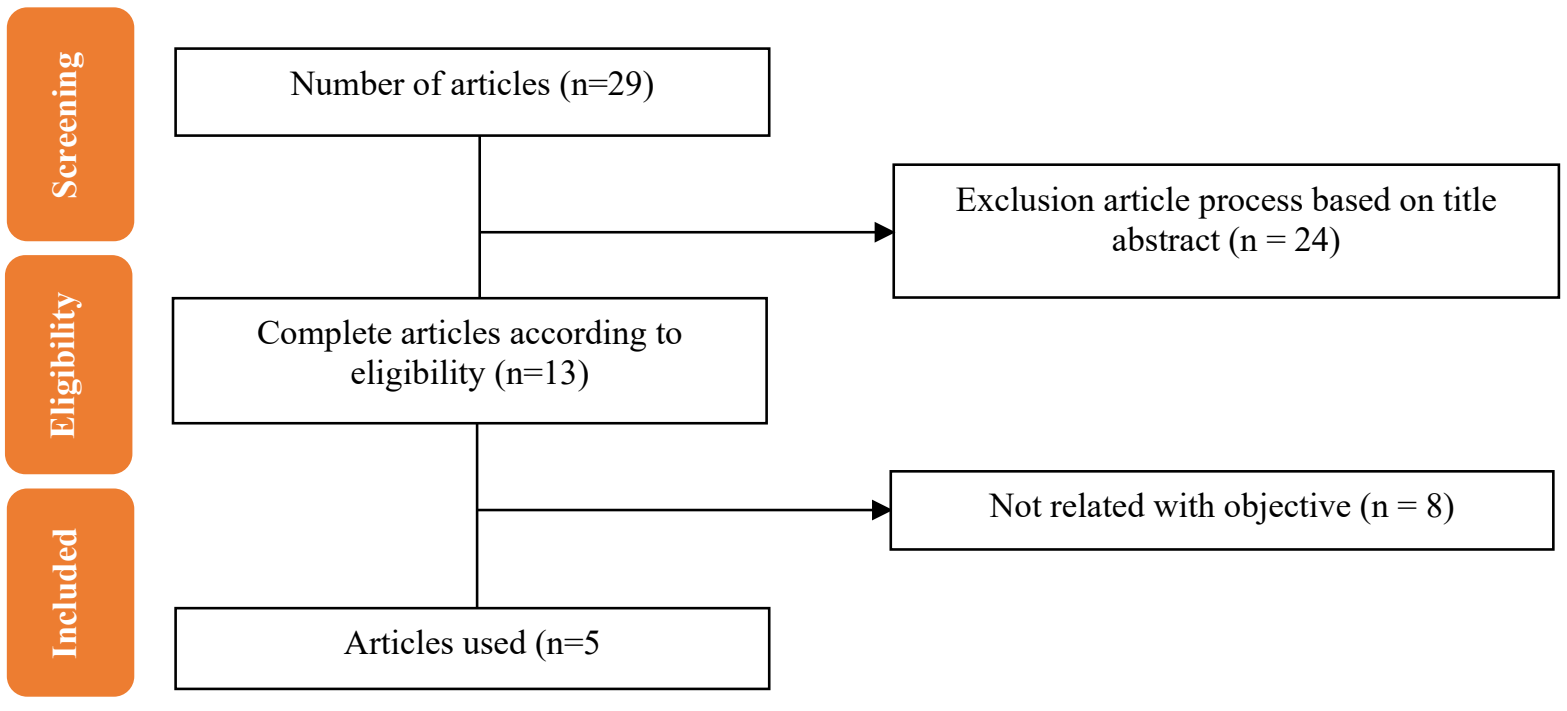

Gambar 1. Bagan alur review artikel yang diteliti

\section{Hasil dan Pembahasan}

Tabel 1. Tabel review artikel

\begin{tabular}{|c|c|c|c|c|}
\hline Artikel & Design & Sampel & $\begin{array}{c}\text { Prosedur } \\
\text { Pengumpulan Data }\end{array}$ & Hasil \\
\hline $\begin{array}{l}\text { Einvik G, Dammen } \\
\text { T, Ghanima W, } \\
\text { Heir T, Stavem K } \\
\text { (Einvik et al., 2021) }\end{array}$ & Studi kohort & $\begin{array}{l}\text { Penyintas covid } 19 \\
\text { yang di rawat inap } \\
\text { sebanyak } 125 \text { orang } \\
\text { dan tidak rawat inap } \\
\text { sebanyak } 458 \text { orang }\end{array}$ & $\begin{array}{l}\text { Data diperoleh dari dua } \\
\text { survei pos / web } \\
\text { campuran pada Juni- } \\
\text { September } 2020 \text { dari } \\
\text { pasien yang semuanya } \\
\text { berusia } \geq 18 \text { tahun } \\
\text { dengan Coronavirus-2 } \\
\text { (SARS-CoV-2) hingga } \\
1 \text { Juni 2020, yang } \\
\text { terdiri dari subjek } \\
\text { rawat inap dan non } \\
\text { rawat inap. }\end{array}$ & $\begin{array}{l}\text { Prevalensi PTSD } \\
\text { berdasarkan gejala } \\
\text { adalah } 9,5 \% \text { di } \\
\text { rawat inap dan } \\
7,0 \% \text { pada subyek } \\
\text { tidak rawat inap (p } \\
=0,80 \text { ). Jenis } \\
\text { kelamin perempuan } \\
\text { dan dispnea selama } \\
\text { COVID-19 adalah } \\
\text { faktor risiko gejala } \\
\text { PTSD yang } \\
\text { persisten. } \\
\text { Pada subjek yang } \\
\text { tidak dirawat di } \\
\text { rumah sakit, depresi } \\
\text { sebelumnya dan } \\
\text { beban gejala } \\
\text { COVID-19 juga } \\
\text { dikaitkan dengan } \\
\text { gejala PTSD yang } \\
\text { persisten. }\end{array}$ \\
\hline $\begin{array}{l}\text { Wu C, Cheng J, } \\
\text { Zou J, Duan L, } \\
\text { Campbell } \\
\text { (Cheng et al., 2021) }\end{array}$ & Kualitatif & $\begin{array}{l}16 \text { orang penyintas } \\
\text { COVID-19 yang } \\
\text { dirawat di rumah }\end{array}$ & $\begin{array}{l}\text { Dilakukan } \\
\text { menggunakan } \\
\text { wawancara telepon }\end{array}$ & $\begin{array}{l}\text { Studi ini } \\
\text { memberikan bukti } \\
\text { empiris pertama } \\
\text { dan kerangka kerja }\end{array}$ \\
\hline
\end{tabular}


JURNAL ILMU KESEHATAN BHAKTI HUSADA:

HEALTH SCIENCES JOURNAL

VOL. 12 NO. 02, DESEMBER 2021

DOI: $\underline{10.34305 / J I K B H . V 12 I 2.327}$
Ciptaan disebarluaskan di bawah

Lisensi Creative Commons Atribusi-

NonKomersial-BerbagiSerupa 4.0

Internasional.

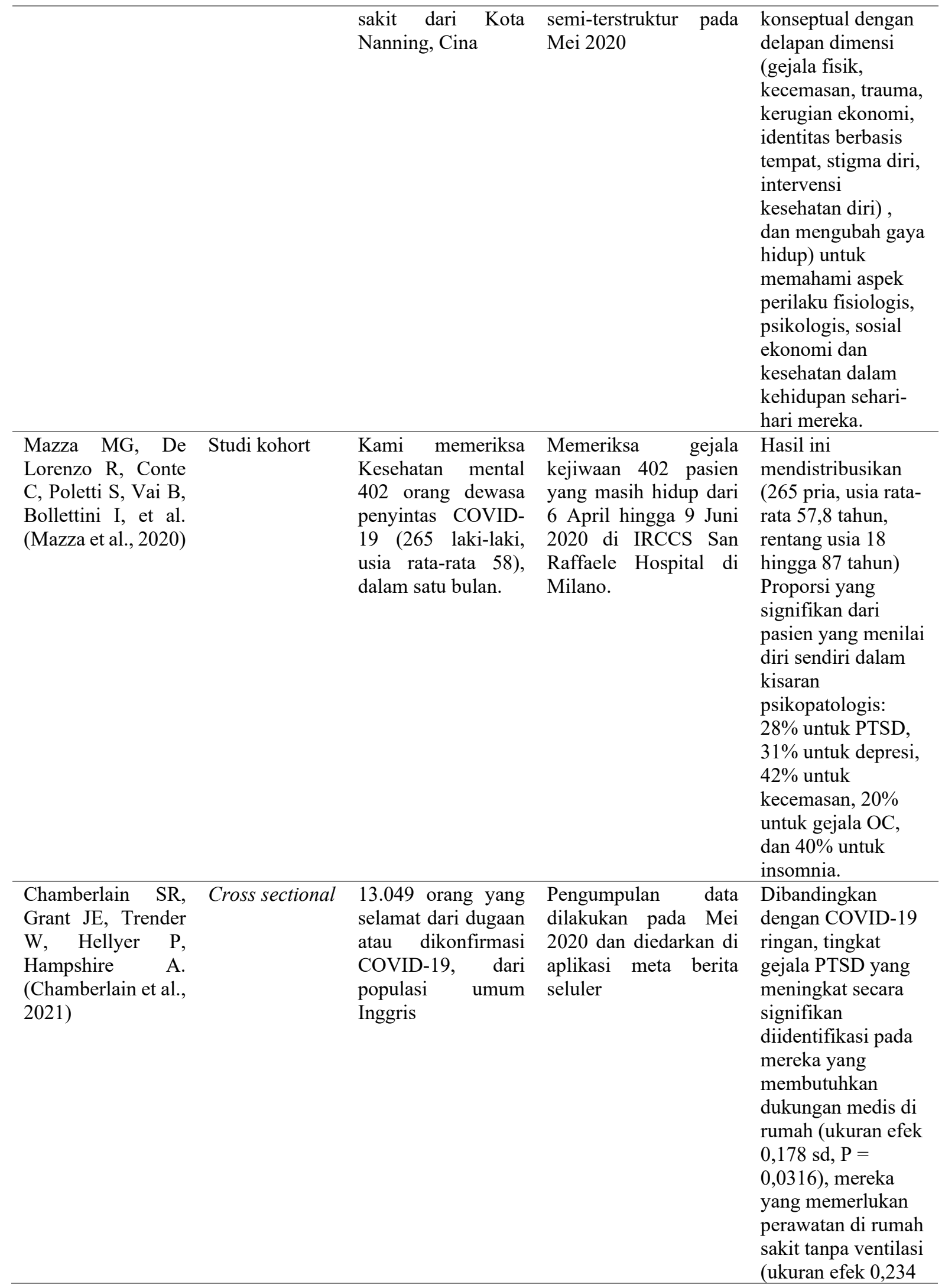


JURNAL ILMU KESEHATAN BHAKTI HUSADA:

HEALTH SCIENCES JOURNAL

VOL. 12 NO. 02, DESEMBER 2021

DOI: $\underline{10.34305 / J I K B H . V 12 I 2.327}$
Ciptaan disebarluaskan di bawah

Lisensi Creative Commons Atribusi-

NonKomersial-BerbagiSerupa 4.0

Internasional

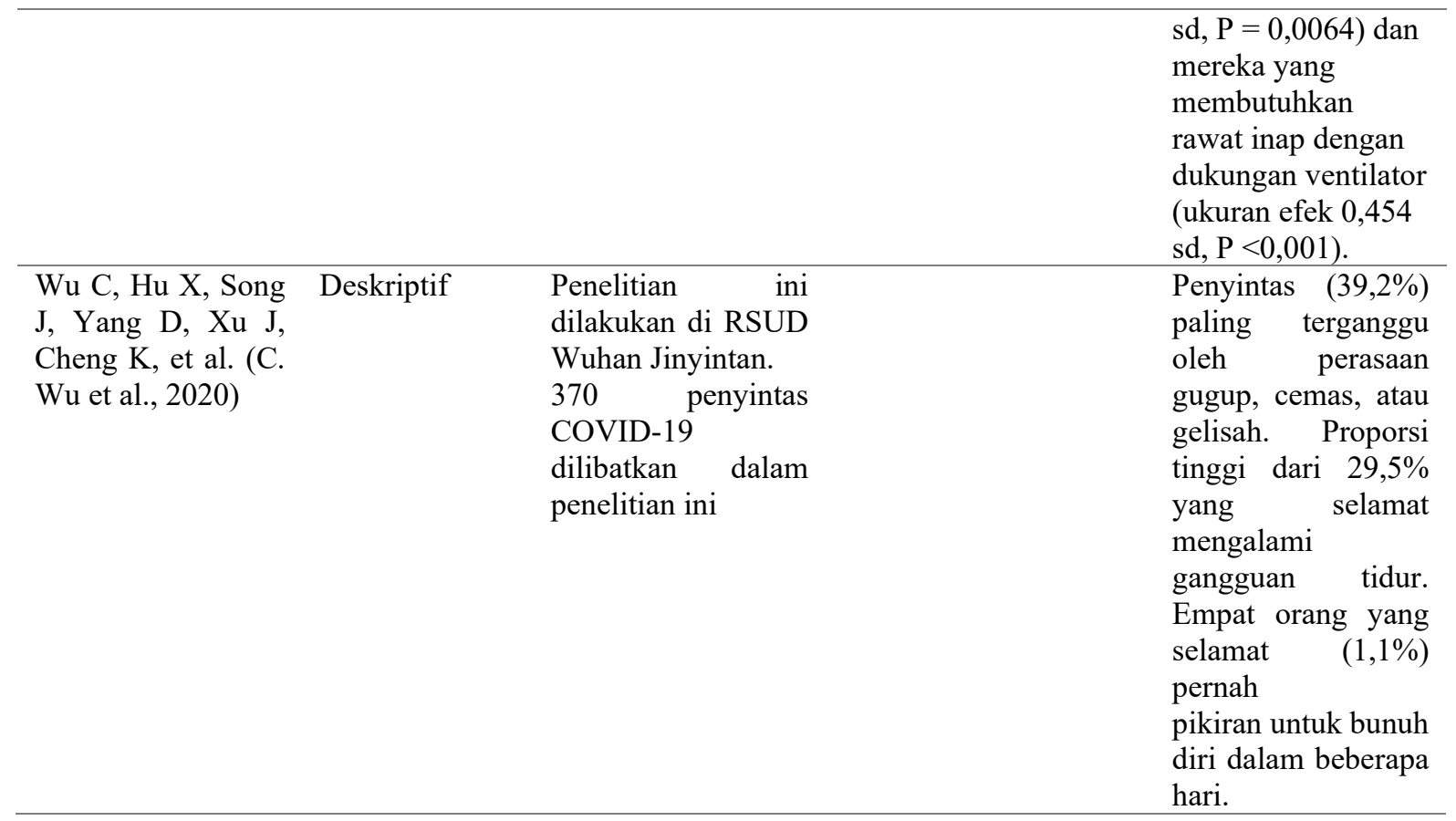

Hasil studi literatur menunjukkan bahwa penyintas COVID-19 rentan untuk mengalami gangguan kesehatan mental. Studi di China bahwa gangguan mental sering menyertai para penyintas COVID-19. Beberapa gangguan mental dimaksud antara lain; ansietas, depresi, PTSD, insomnia (Ma et al., 2020). Penelitian lain serupa yang telah dipublikasi, menjelaskan bahwa gangguan mental para penyintas COVID-19 dilaporkan mengalami perasaan gugup, cemas atau gelisah, gangguan tidur (Mazza et al., 2020). Bahkan Penelitian di Wuhan melaporkan penyintas pernah memikirkan untuk bunuh diri (C. Wu et al., 2020). Adanya gangguan kesehatan mental terjadi akibat adanya perubahan signifikan yang terjadi pada kehidupan. Peristiwa traumatis menjadi penyebab salah satu keadaan ini. Hal ini dapat terjadi pada korban / penyintas, penolong maupun saksi yang mengalami peristiwa tersebut. Pada penyintas COVID19 mereka mengalami perubahan kehidupan yang signifikan. Perubahan yang dialami diantaranya adalah kehidupan sosial dimana mereka harus melakukan physcal distancing dan juga perubahan gaya hidup dimana mereka harus menerapkan protokol kesehatan dan tetap mengkonsumsi makanan sehat dan multivitamin untuk tetap meningkatkan imunitasnya.

Masalah kesehatan mental dapat terjadi akibat adanya faktor predisposisi dan presipitasi yaitu adanya stressor yang berupa 
JURNAL ILMU KESEHATAN BHAKTI HUSADA:

HEALTH SCIENCES JOURNAL

VOL. 12 NO. 02, DESEMBER 2021

DOI: $\underline{10.34305 / J I K B H . V 12 I 2.327}$
Ciptaan disebarluaskan di bawah

Lisensi Creative Commons Atribusi-

NonKomersial-BerbagiSerupa 4.0

Internasional stresor biologis, psikologis dan sosial yang dialami oleh individu. Stressor biologis berkaitan dengan keadaan genetik ataupun penyakit yang diderita beserta gejalanya (Stuart, 2013). Gejala yang dialami oleh penderita COVID-19 beragam dari ringan sampai berat seperti, demam, batuk, hilangnya kemampuan perasa atau penciuman bahkan sampai sesak nafas (Ma et al., 2020). Gejala ini masih dapat dirasakan sebagai long covid walaupun sudah dinyatakan negatif. Penelitian di Wuhan bahkan mengungkapkan bahwa ketika penyintas melakukan pemeriksaan ulang fisik mereka menunjukkan beberapa nilai abnormal (misalnya sisa peradangan di paru-paru/pneumonia, atau tidak adanya antibodi SARS-CoV-2), yang membuat penyintas khawatir tentang gejala sisa yang merugikan akibat pemulihan yang tidak tuntas (Mazza et al., 2020). Selain itu, penyintas yang sebelumnya mengalami gejala berat memiliki tekanan psikologis yang lebih tinggi pada tahap pemulihan awal. Dalam periode ini, mereka sangat sensitif dan sadar akan gejala fisik mereka karena mereka khawatir apakah mereka sembuh total atau akan menjalani tes RNA positif lebih lanjut. Beberapa penelitian bahkan melaporkan adanya hasil positif yang dapat dideteksi ulang dari tes COVID19 RNA pada beberapa pasien yang pulih (Qiu et al., 2021), atau dapat dikatakan reinfeksi (Cheng et al., 2021). Pada masalah kesehatan mental berupa kecemasan memiliki hubungan yang signifikan dengan gejala sisa pasca kepulangan, khawatir tentang kekambuhan, dan khawatir tentang infeksi pada orang lain (C. Wu et al., 2020). Artinya, kekhawatiran mengenai status fisiknya baik sudah ada atau tidak adanya virus serta ada atau tidak adanya gejala sisa pasca perawatan menimbulkan yang menjadi stressor masalah kesehatan mental pada penyintas COVID-19.

Pada stressor psikologis, diakibatkan karena adanya pengalaman yang tidak menyenangkan di masa lalu (Stuart, 2013). Kecemasan yang dialami oleh penyintas sama seperti pandemi yang pernah terjadi sebelumnya. Penelitian mengenai pandemi SARS telah menunjukkan bahwa orang yang selamat bisa mengembangkan gangguan psikologis jangka panjang. Gangguan psikologis dilaporkan dapat terjadi lebih dari 1 tahun (Mazza et al., 2020). Pada penyintas COVID-19, semua penyintas COVID-19 disarankan untuk menjalani gaya hidup karantina pasca-pulang dari rumah sakit selama 2 minggu. Gaya hidup yang 
JURNAL ILMU KESEHATAN BHAKTI HUSADA:

HEALTH SCIENCES JOURNAL

VOL. 12 NO. 02, DESEMBER 2021

DOI: $\underline{10.34305 / J I K B H . V 12 I 2.327}$

dimaksud yaitu karantina rumah termasuk tinggal di kamar berangin tunggal, pengurangan kontak dekat dengan keluarga, makan terpisah, dan menghindari aktivitas di luar ruangan. Perilaku ini diperlukan untuk menghindari infeksi tak terduga pada orang lain. Namun, hasil studinya menunjukkan bahwa gaya hidup isolasi di rumah erat dengan peningkatan insiden depresi, dan pada penyintas dengan jenis kelamin perempuan cenderung lebih rentan mengalami depresi (C. Wu et al., 2020). Sedangkan masalah kesehatan mental PTSD menunjukkan bahwa klien yang pernah dirawat inap, mengalami PTSD dengan gejala lebih berat dibandingkan dengan mereka yang menjalankan isolas mandiri (Einvik et al., 2021). Masalah kesehatan lain yang ditemukan yaitu PTSD. Penelitian sebelumnya yang berkaitan dengan penyakit pandemi yang sifatnya menular yaitu SARS, penyintas pandemic SARS bahwasanya 59 persen dari mereka yang sepenuhnya memenuhi diagnosis PTSD (Ma et al., 2020). Hal ini juga ditemukan pada penyintas COVID-19. Bahkan, berdasarkan data karakteristik perawatan, klien yang pernah dirawat inap, mengalami PTSD dengan gejala lebih berat dibandingkan dengan mereka yang menjalankan isolasi
Ciptaan disebarluaskan di bawah Lisensi Creative Commons AtribusiNonKomersial-BerbagiSerupa 4.0

Internasional

mandiri (Einvik et al., 2021). Bahkan, tingkat gejala PTSD yang meningkat secara signifikan diidentifikasi pada mereka yang membutuhkan dukungan medis di rumah (ukuran efek 0,178 sd, $\mathrm{P}=0,0316$ ), mereka yang memerlukan perawatan di Rumah Sakit tanpa ventilasi (ukuran efek 0,234 sd, $\mathrm{P}=$ 0,0064) dan mereka yang membutuhkan rawat inap dengan dukungan ventilator (ukuran efek 0,454 sd, $\mathrm{P}<0,001$ ) (Forte et al., 2020). Hal ini menandakan bahwa perawatan isolasi selama sakit dan isolasi 14 hari setelah sakit merupakan pengalaman yang dapat menimbulkan masalah kesehatan mental kepada penyintas yang berupa kecemasan dan depresi. Selain itu tindakan invasive yang diberikan selama perawatan juga berpengaruh terhadap terjadinya masalah kesehatan mental pada penyintas.

Stressor sosial erat kaitannya dengan hubungan social penyintas dengan lingkungan sekitarnya. Secara eksternal penyintas COVID-19 telah menjadi kelompok rentan yang dikucilkan dari banyak kegiatan sosial dan ekonomi. Pertama, kebocoran data pribadi termasuk nama, afiliasi dan lokasi telah meningkatkan stigma sosial terhadap kelompok ini. Hal ini dapat disebabkan oleh pengetahuan terkait COVID-19 yang tidak jelas adalah 
JURNAL ILMU KESEHATAN BHAKTI HUSADA:

HEALTH SCIENCES JOURNAL

VOL. 12 NO. 02, DESEMBER 2021

DOI: $\underline{10.34305 / J I K B H . V 12 I 2.327}$

parameter yang mengarah pada tanggapan negatif orang lain terhadap penyintas (Cheng et al., 2021). Di Indonesia hasil survei menunjukkan bahwa fenomena stigma terkait COVID-19 nyata adanya dan stigma sosial tidak hanya dikenakan terhadap mereka yang terpapar COVID-19, namun dikenakan juga kepada penyintas COVID19 (Ratnawulan \& Pelupessy, 2021). Selain menderita COVID-19, pengalaman traumatis termasuk gangguan terus menerus dan reaksi negatif (misalnya menyalahkan, bergosip) dari masyarakat memperburuk tekanan psikologis dan kecemasan para penyintas (Cheng et al., 2021). Setelah keluar dari rumah sakit, penyintas menerima tatapan aneh dan merasa sengaja dihindari oleh banyak orang. Juga, menemukan bahwa penyintas COVID-19 telah mengalami stigma dari anggota komunitasnya, yang mengarah ke bentuk kematian sosial (Obuobi Asare, 2020). Seperti yang ditunjukkan dalam penelitian sebelumnya, orang yang selamat dari SARS (Siu, 2008) dan Ebola (Hanson et al., 2016) rentan terhadap rasa malu dan stigma. Dalam akun ini, banyak penyintas cenderung menginternalisasi perilaku dan sikap eksklusif orang lain terhadap mereka, mengakibatkan penurunan harga diri dan
Ciptaan disebarluaskan di bawah Lisensi Creative Commons AtribusiNonKomersial-BerbagiSerupa 4.0 Internasional. perasaan prasangka yang meningkat yang menyebabkan perasaan sedih, suasana hati yang rendah, depresi, dan sulit tidur (Cheng et al., 2021). Selain stigma yang didapat oleh pihak eksternal, penyintas juga rentan mengalami oleh kekhawatiran sendiri (perceived stigma). Penelitian menyebutkan bahwa penyintas mengkhawatirkan status fisik mereka sudah benar-benar sembuh atau belum. Penyintas mengalami perasaan khawatir menularkan kepada keluarga. Terlebih, kasus kluster keluarga adalah salah satu pola khas COVID-19 infeksi yang disebabkan oleh penularan dari orang ke orang (Liu et al., 2020). Studi menyebutkan bahwa ketika anggota keluarga terinfeksi COVID-19 secara bersamaan, konsekuensi psikologis yang diterimanya lebih besar (Cheng et al., 2021). Ketidakpastian tentang status fisik mereka menyebabkan stigma diri (Cheng et al., 2021). Hal ini menunjukkan bahwa permasalahan stigma baik yang disebabkan oleh eksternal maupun internal berpotensi untuk menjadi penyebab masalah kesehatan mental pada penyintas COVID19. Bunuh diri dapat terjadi sebagai dampak masalah-masalah kesehatan mental yang tidak mampu diatasi dengan baik.

\section{Kesimpulan dan Saran}


JURNAL ILMU KESEHATAN BHAKTI HUSADA:

HEALTH SCIENCES JOURNAL

VOL. 12 NO. 02, DESEMBER 2021

DOI: $\underline{10.34305 / J I K B H . V 12 I 2.327}$

Penyintas COVID-19 rentan untuk mengalami masalah kesehatan mental seperti kecemasan, depresi, PTSD bahkan bunuh diri. Guna mengatasi hal tersebut perlu adanya layanan konsultasi yang efektif untuk mendukung penyintas COVID-19 yang dipulangkan ataupun yang telah selesai melaksanakan masa isolasi mandiri di rumah, seperti penjelasan gejala fisik atau implikasi medis dari hasil tes ulang. Kemudian diperlukan adanya inovasi sosial dalam menanggapi bencana yang muncul guna menurunkan stigma sosial di masyarakat.

\section{Daftar Pustaka}

Chamberlain, S. R., Grant, J. E., Trender, W., Hellyer, P., \& Hampshire, A. (2021). Post-Traumatic Stress Disorder Symptoms in COVID-19 Survivors: Online Population Survey. BJPsych Open, 7(2).

Cheng, J., Wu, C., Zou, J., Duan, L., \& Campbell, J. (2021). Health-Related Quality of Life of Hospitalized COVID-19 Survivors: An Initial Exploration in Nanning City, China. Social Science \& Medicine, 274. https://doi.org/10.1016/j.socscimed.20 21.113748

Einvik, G., Dammen, T., Ghanima, W., Heir, T., \& Stavem, K. (2021). Prevalence and Risk Factors for Post-Traumatic Stress in Hospitalized and NonHospitalized COVID-19 Patients.
Ciptaan disebarluaskan di bawah Lisensi Creative Commons AtribusiNonKomersial-BerbagiSerupa 4.0 Internasional.

International Journal of Environmental Research and Public Health, 18(4), 2079.

Forte, G., Favieri, F., Tambelli, R., \& Casagrande, M. (2020). COVID-19 Pandemic in the Italian Population: Validation of A Post-Traumatic Stress Disorder Questionnaire and Prevalence of PTSD Symptomatology. International Journal of Environmental Research and Public Health, 17(11), 4151.

Hanson, J., Decosimo, A., \& Quinn, M. (2016). Diminished Quality of Life Among Women Affected by Ebola. Journal of Social, Behavioral, and Health Sciences, 10(1), 11.

Liu, C. H., Zhang, E., Wong, G. T. F., \& Hyun, S. (2020). Factors Associated With Depression, Anxiety, and PTSD Symptomatology During the COVID19 Pandemic: Clinical Implications for Us Young Adult Mental Health. Psychiatry Research, 290, 113172.

Ma, K., Wang, X., Feng, S., Xushan, X., Zhang, H., Rahaman, A., Dong, Z., Lu, Y., Li, X., \& Zhou, X. (2020). From the Perspective of Traditional Chinese Medicine: Treatment of Mental Disorders in COVID-19 Survivors. Biomedicine \& Pharmacotherapy, 110810.

Mazza, M. G., De Lorenzo, R., Conte, C., Poletti, S., Vai, B., Bollettini, I., Melloni, E. M. T., Furlan, R., Ciceri, F., \& Rovere-Querini, P. (2020). Anxiety and Depression in COVID-19 Survivors: Role of Inflammatory and Clinical Predictors. Brain, Behavior, and Immunity, 89, 594-600. 
JURNAL ILMU KESEHATAN BHAKTI HUSADA:

HEALTH SCIENCES JOURNAL

VOL. 12 NO. 02, DESEMBER 2021

DOI: $\underline{10.34305 / J I K B H . V 12 I 2.327}$

Obuobi Asare, N. (2020). Stigma as a Social Death for COVID-19 Survivors in Ghana.

Qiu, D., Li, Y., Li, L., He, J., Ouyang, F., \& Xiao, S. (2021). Prevalence of PostTraumatic Stress Symptoms Among People Influenced by COVID-19 Outbreak: A Meta-Analysis. European Psychiatry, 1-42.

Ratnawulan, I., \& Pelupessy, D. C. (2021). Mengurangi Stigma Sosial terhadap Penyintas COVID-19 melalui Metode Kontak Bayangan. Jurnal Penelitian Pendidikan, Psikologi Dan Kesehatan (J-P3K), 2(1), 52-60.

Siu, J. Y. (2008). The SARS-Associated Stigma of SARS Victims in the PostSARS Era of Hong Kong. Qualitative Health Research, 18(6), 729-738.

Stuart, G. W. (2013). Principles and Practice of Psychiatric Nursing (10th editi). Missoury: Mosby.

Susilo, A., Rumende, C. M., Pitoyo, C. W., Santoso, W. D., Yulianti, M., Herikurniawan, H., Sinto, R., Singh, G., Nainggolan, L., \& Nelwan, E. J. (2020). Coronavirus Disease 2019: Tinjauan Literatur Terkini. Jurnal Penyakit Dalam Indonesia, 7(1), 4567.

Wu, C., Hu, X., Song, J., Yang, D., Xu, J., Cheng, K., Chen, D., Zhong, M., Jiang, J., \& Xiong, W. (2020). Mental Health Status and Related Influencing Factors of COVID-19 Survivors in Wuhan, China. Clinical and Translational Medicine, 10(2), e52.
Ciptaan disebarluaskan di bawah

Lisensi Creative Commons Atribusi-

NonKomersial-BerbagiSerupa 4.0

Internasional.

Wu, K. K., Chan, S. K., \& Ma, T. M. (2005). Posttraumatic Stress, Anxiety, and Depression in Survivors of Severe Acute Respiratory Syndrome (SARS). Journal of Traumatic Stress: Official Publication of The International Society for Traumatic Stress Studies, 18(1), 39-42. 